Jurnal Ekonomi dan Bisnis Islam (Journal of Islamic Economics and Business)

Volume I, Nomor 2, Oktober 2016

ISSN: 2527-3434 (PRINT) - ISSN: 2527-5I43 (ONLINE)

Page: 196-208

\title{
PENGARUH KUALITAS PELAYANAN DENGAN KEPUASAN KONSUMEN PADA PT. PUSRI PALEMBANG PPD LAMPUNG
}

\author{
Yudiana Sari \\ STIE Satu Nusa Bandar Lampung \\ Yudiana.sariI9@gmail.com
}

\begin{abstract}
The research object of this research is PT. PUSRI PPD Lampung Palembang. PT Pusti arranged subsidized fertilizer marketing services in specific areas (rayonisasi) and the Minister of Industry Decree 356 / MPP / Kep / 5/2004 for the smooth distribution of subsidized fertilizers which are the responsibility of manufacturers, authorized distributors and authorized retailers. The problem under study is to analyze the effect of service quality on customer satisfaction at PT. PUSRI Lampung Palembang PPD due to sales of PT. PUSRI PPD Lampung Palembang. The method used in this research is the research literature and field research conducted by examining directly on PT. PUSRI PPD Lampung Palembang. The results showed that the calculation formula product moment correlation that is equal to 0.804 with $n=55$. The number is located on the interval coefficient of 0.75 to $I$, which means the relationship between service quality and customer satisfaction in the volume of sales at PT. PUSRI Lampung Palembang PPD is very strong.
\end{abstract}

Keywords : Service Quality, Customer Satisfaction, Volume Sales

\begin{abstract}
Abstrak-Objek penelitian dari penelitian ini adalahPT. PUSRI Palembang PPD Lampung. PT Pusri diatur pelayanan pemasaran pupuk bersubsidi dalam wilayah-wilayah tertentu (rayonisasi) dan SK Menperindag No.356/MPP/Kep/5/2004 untuk kelancaran pendistribusian pupuk bersubsidi yang menjadi tanggung jawab produsen, distributor resmi dan pengecer resmi. Permasalahan yang diteliti adalah ingin menganalisis pengaruh kualitas pelayanan terhadap kepuasan konsumen pada PT. PUSRI Palembang PPD Lampung karena realisasi penjualan PT. PUSRI Palembang PPD Lampung. Metode penelitian yang digunakan dalam penelitian ini adalah penelitian kepustakaan dan penelitian lapangan dilakukan dengan meneliti langsung pada PT. PUSRI Palembang PPD Lampung.Hasil penelitian menunjukkan bahwa perhitungan dengan rumus korelasi product moment yaitu sebesar 0,804 dengan $\mathrm{n}=55$. Angka tersebut terletak pada interval koefisien 0,75 - I yang berarti hubungan antara kualitas pelayanan dengan kepuasan pelanggan dalam meningkatkan volume penjualan pada PT. PUSRI Palembang PPD Lampung adalah sangat kuat.
\end{abstract}

Kata Kunci : Kualitas Pelayanan, KepuasanKonsumen, Volume Penjualan

Received :Juli 2016 Revised: I6 Agustus 2016 Accepted : 05 September 2016

STIE Satu Nusa Bandar Lampung

E-mail:Yudiana.sari19@gmail.com 


\section{PENDAHULUAN}

PT. Pupuk Sriwidjaja, merupakan Badan Usaha Milik Negara yang bergerak di bidang produksi dan pemasaran pupuk.Masalah utama pada PT. PUSRI Palembangdalam pelayanan konsumen yang banyak pesaingnya adalah pelayanan yang diberikan apakah sudah sesuai harapan konsumen atau belum.Menjalin hubungan dan melakukan penelitian terhadap mereka perlu dilakukan agar pelayanan yang diberikan sesuai dengan yang diharapkan (Selvy,Vol. 6 No. 2 Desember 2013).

Berdasarkan latar belakang yang telah dikemukakan sebelumnya konteks dari permasalahan yang ada adalah:

I. Realisasi penjualan PT. PUSRI Palembang terkadang hampir mencapai I00\% dari target yang ditentukan, namun terkadangjauh dari target yang ditentukan PT. PUSRI Palembang

2. Ingin menganalisis pengaruh kualitas pelayanan terhadap kepuasan konsumen pada PT. PUSRI Palembang PPD Lampung.

Menurut (Berry dan Zenthaml dalam Lupiyoadi, 2006:I8I) berpendapat bahwa "Keberhasilan perusahaan dalam memberikan pelayanan yang berkualitas dapat ditentukan dengan pendekatan service quality'Kepuasan konsumen sesudah pembelian tergantung dari kinerjapenawaran dibandingkan dengan harapannya, dimana harapan itu sendirimerupakan fase awal dari individu dalam mengonsumsi sebuah produk.

Dalam tahap evaluasi, harapan konsumen digunakan sebagai pembanding denganpersepsi dalammenilai kualitas sebuah produk.Kepuasan adalah tingkat perasaan seseorang setelah membandingkankinerja (atau hasil) yang dia rasakan dibandingkan dengan harapannya (Catur Martian Fajar, IkonomikaVolume I, Nomor I, Mei 2016).

Volume penjualan meruapakan jumlah total yang dihasilkan dari kegiatan penjualan barang. Semakin besar jumlah penjualan yang dihasilkan perusahaan, semakin besar kemungkinan laba yang akan dihasilkan perusahaan. Jadi volume penjualan yang menguntungkan harus menjadi tujuan utama perusahaan dan bukannya untuk kepentingan volume penjualan itu sendiri(Auli, Management AnalysisJournal, 2 (I) (2013). 


\section{METODE PENELITIAN}

Untuk mendapatkan data dalam penelitian ini, penulis menggunakan dua rancangan penelitian sebagai berikut :

I. Penelitian Kepustakaan

2. Penelitian Lapangan

Sumber data yang digunakan untuk penelitian ini adalah data primer dan data sekunder. Teknik pengumpulan data yang dilakukan adalah denganmenggunakan teknik simple random sampling.Teknik ini dipilih karenaketerbatasan peneliti baik dari segi waktu maupun biaya.Teknik ini dilakukandengan memberi nomornomor pada seluruh anggota populasi, kemudiansecara acak dipilih nomornomor sesuai dengan banyaknya jumlah sampelyang dibutuhkan. Untuk menentukan besarnya sampel (dalam penelitian ini)dari populasi tersebut di atas, digunakan teori ukuran sampel yangdikemukakan 20II:I4I),yaitu :

(Umar,

$$
N=\frac{N}{1+N e^{2}}
$$

Dimana:

$\mathrm{n}=$ Ukuran sampel.

$\mathrm{N}=$ Ukuranpopulasi.

$\mathrm{e}=$ Persen kelonggaran

ketidaktelitian karena masalah pengambilansampel yang masih ditolelir sebesar I0\%.
Jadi berdasarkanrumus diatas maka besarnya sampel dalam penelitiandihitung sebagai berikut :

$$
N=\frac{120}{1+(120 \times 0.01)}=55
$$

Uji validitas digunakan untuk mengetahui valid tidaknya setiap pertanyaan yang diajukan kepada responden dengan menggunakan koefisien korelasi product moment menurut (Husein Umar, 20II:I78), yang rumusnya sebagai berikut :

$$
r_{x y}=\frac{N \sum X Y-\left(\sum X\right)\left(\sum Y\right)}{\sqrt{\left\{N \sum X^{2}-\left(\sum X\right)^{2}\right\}\left\{N \sum Y^{2}-\left(\sum Y\right)^{2}\right\}}}
$$

Keterangan :

$\mathrm{r}_{\mathrm{xy}}=$ Hubungan peubah $\mathrm{X}$ terhadap $\mathrm{Y}$

$\mathrm{X}=$ Jumlah skor per pertanyaan

$\mathrm{Y}=$ Jumlah skor keseluruhan pertanyaan

$\mathrm{n}=$ Jumlah perespon

Rumus pengujian reliabilitas instrumen dengan teknik cronbach adalahsebagai berikut :

$$
r_{11}=\left[\frac{k}{k-1}\right]\left[1-\frac{\sum \sigma_{b}^{2}}{\sigma_{b}^{2}}\right]
$$

Keterangan:

$\mathrm{r}_{11}=$ Tingkat reliabilitas instrumen

$\mathrm{k}=$ Banyak butir pertanyaan

$\sigma_{\mathrm{b}}{ }^{2}=$ Jumlah varians butir

$\sigma_{\mathrm{b}}{ }^{2} \quad=$ Jumlah variabel total 
Jumlah varians butir diperoleh dengan menjumlahkan nilai-nilai varians tiapbutir. Rumus varians yang digunakan adalah sebagai berikut :

$$
\sigma=\frac{\left(\sum X\right)^{2}\left[\frac{\sum x}{n}\right]^{2}}{n}
$$

Keterangan :

$\mathrm{n} \quad=$ Jumlah responden

$\mathrm{X} \quad=$ Nilai skor yang dipilih

Pengolahan data untuk uji reliabilitas menggunakan bantuan computerdengan program SPSS versi 13.00.Setelah kuesioner diuji kelayakan dan kehandalannya melalui uji validitas danuji reliabilitas, dan dinyatakan valid serta reliabel, lalu semua datadikumpulkan dan diolah kemudian dianalisis secara kualitatif yaitu analisishubungan kualitas pelayanan dengan kepuasan konsumen, selanjutnyadiuraikan dalam bentuk kalimat yang tersusun secara sistematis kemudiandilakukan pembahasan yang pada akhirnya dapat ditarik kesimpulan tentangmasalah-masalah yang diteliti.

Analisis ini digunakan untuk mengetahui sebagaimana erat hubungan kualitaspelayanan dengan kepuasan konsumen dalam meningkatkan volumepenjualan pada PT. PUSRI Palembang PPD Lampung dengan menggunakan rumuskorelasiproduct moment (Umar, 20II: I78-180) sebagai berikut :

$$
r_{x y}=\frac{N \sum X Y-\left(\sum X\right)\left(\sum Y\right)}{\sqrt{\left\{N \sum X^{2}-\left(\sum X\right)^{2}\right\}\left\{N \sum Y^{2}-\left(\sum Y\right)^{2}\right\}}}
$$

Keterangan:

$\mathrm{r}_{\mathrm{xy}}=$ Koefisien korelasi (keeratan hubungan) kualitas pelayanan dengan

kepuasan konsumen

$\mathrm{X}=$ Kualitas pelayanan sebagai variabel bebas

$\mathrm{Y}=$ Kepuasan konsumen sebagai variabel

terikat

$\mathrm{n}=$ Jumlah responden

Untuk pengujian hipotesis terhadap $r$ dapat menggunakan statistik $t$ denganrumus sebagai berikut:

$$
T=\frac{r \sqrt{N-2}}{\sqrt{1-r^{2}}} \text { Dengan } \mathrm{df}=\mathrm{n}-2
$$

Kriteria Hipotesis :

a. Jika $t$ hitung $>t$ tabel maka Ho ditolak dan menerima $\mathrm{Ha}$. yang berarti adahubungan antara kualitas pelayanan dengan kepuasan konsumen.

b. Jika $t$ hitung $<\mathrm{t}$ tabel maka Hoditerima dan menolak $\mathrm{Ha}$ ymg berarti tidakada hubungan antara kualitas pelayanan dengan kepuasan konsumen. 
Besar kecilnya korelasi Keterangan:

menentukan kuat atau lemahnya $r_{x y} \quad=$ Koefisien korelasi (keeratan

hubungan keduavariabel dapat menggunakan patokan angka sebagai berikut (Sarwono,2013:86-87):

I) $0-0,25=$ Korelasi sangat lemah (dianggap tidak ada)

2) $>0,25-0,5=$ Korelasi cukup

3) $>0,5-0,75=$ Korelasi kuat

4) $>0,75-I=$ Korelasi sangatkuat

\section{HASIL DAN PEMBAHASAN}

Setelah kuesioner diuji kelayakan dan kehandalannya melalui uji validitas danuji reliabilitas, dan dinyatakan valid serta reliabel, lalu semua datadikumpulkan dan diolah kemudian dianalisis secara kualitatif yaitu analisishubungan kualitas pelayanan dengan kepuasan konsumen.

Analisis ini digunakan untuk mengetahui sebagaimana erat hubungan kualitaspelayanan dengan kepuasan konsumen dalam meningkatkan volumepenjualan pada PT. PUSRI Palembang PPD Lampung dengan menggunakan rumuskorelasiproduct moment (Umar, 20II:I78-I80) sebagai berikut :

$$
\begin{aligned}
& r_{x y} \\
& =\frac{N \sum X Y-\left(\sum X\right)\left(\sum Y\right)}{\sqrt{\left\{N \sum X^{2}-\left(\sum X\right)^{2}\right\}\left\{N \sum Y^{2}-\left(\sum Y\right)^{2}\right\}}}
\end{aligned}
$$

$$
\begin{aligned}
& \begin{array}{l}
\text { hubungan) kualitas pelayanan } \\
\text { dengankepuasankonsumen }
\end{array} \\
\mathrm{X}= & \text { Kualitas pelayanan sebagai } \\
& \text { variabel bebas } \\
\mathrm{Y} \quad & \text { Kepuasan konsumen sebagai } \\
& \text { variabel terikat } \\
\mathrm{n} \quad= & \text { Jumlah responden }
\end{aligned}
$$

Untuk pengujian hipotesis terhadap $\mathrm{r}$ dapat menggunakan statistik t denganrumus sebagai berikut :

$T=\frac{r \sqrt{N-2}}{\sqrt{1-r^{2}}}$ Dengan $\mathrm{df}=\mathrm{n}-2$

Kriteria Hipotesis :

Jika $\mathrm{t}$ hitung $>\mathrm{t}$ tabel maka Ho ditolak dan menerima Ha.yang berarti adahubungan antara kualitas pelayanan dengan kepuasan konsumen.

Jika $\mathrm{t}$ hitung $<\mathrm{t}$ tabel maka Hoditerima dan menolak Ha yang berarti tidakada hubungan antara kualitas pelayanan dengan kepuasan konsumen.

Besar kecilnya korelasi menentukan kuat atau lemahnya hubungan keduavariabel dapat menggunakan patokan angka sebagai berikut (Sarwono,2013:86-87):

0 - 0,25 :Korelasi sangat lemah (dianggap

tidak ada)

$>0,25-0,5:$ Korelasi cukup 
$>0,5-0,75:$ Korelasi kuat

$>0,75-I$ : Korelasi sangatkuat

Validitas adalah suatu ukuran

yang menunjukkan tingkat-tingkat kevalidan ataukesahihan suatu instrumen.Suatu instrumen yang valid atau sahih mempunyaivaliditas yang tinggi.Sebaliknya instrumen yang kurang valid berarti memilikivaliditas yang rendah. Uji validitas dilakukan dengan menggunakan alat analisisproduct moment dan proses perhitungan program statistik SPSS versi I5.00.

Berdasarkan hasil perhitungan uji validitas pada masing-masing variabel bebasyang bersifat mempengaruhi (independent)yaitu kualitas pelayanan dan variabel terikat yang bersifat dipengaruhi (dependent) yaitukepuasan konsumen padasetiap butir pertanyaan diperoleh hasil bahwa semua butir pertanyaan yangdianalisis sudah dinyatakan valid karena nilai $r$ hitung $>$ $r$ tabel, dimana besarnyanilai $r$ tabel diperoleh dengan ketentuan $\mathrm{df}=$ jumlah sampel-2 atau 23-2=2I,dan tingkat signifikansi sebesar 5\%. Angka $r$ tabel yang diperoleh adalah sebesar0,433.

Pengujian reliabilitas adalah untuk melihat tingkat kehandalan kuesioner.Kuesioner yang reliabel adalah kuesioner yang apabila dicoba secara berulang-ulangkepada kelompok yang sama akan menghasilkan data yang sama. Ujireliabilitas menggunakan rumus korelasi Alpha Cronbach dikonsultasikan padatabel $\mathrm{r}$ product moment padan-2 atau 23-2 = 2I, tingkat kepercayaan (df) 95\%dan alpha (a) $5 \%$. Nilai reliabilitas pada masingmasing variable dihitung mengunakan SPSS.

\section{Tabel 2.}

Pertanyaan No. I. Menurut Anda apakah penyambutan yang dilakukan karyawan ketika Andamendatangi PT. PUSRI Palembang PPD Lampung sudah sangat baik

\begin{tabular}{|l|r|r|r|r|}
\hline & Frequency & Percent & \multicolumn{1}{|c|}{$\begin{array}{c}\text { Valid } \\
\text { Percent }\end{array}$} & $\begin{array}{c}\text { Cumulative } \\
\text { Percent }\end{array}$ \\
\hline Valid Sangat Tidak Baik & 5 & 9.1 & $9 . \mathrm{I}$ & $9 . \mathrm{I}$ \\
Tidak Baik & II & 20.0 & 20.0 & $29 . \mathrm{I}$ \\
Cukup Baik & I0 & I8.2 & 18.2 & 47.3 \\
Baik & I9 & 34.5 & 34.5 & 81.8 \\
Sangat Baik & I0 & I8.2 & I8.2 & I00.0 \\
Total & 55 & I00.0 & I00.0 & \\
\hline
\end{tabular}


Pada tabel 2 terlihat pandangan IIrespondenmenyatakan tidak baik, dan responden terhadap penyambutan 5 responden menyatakan sangat tidak yangdilakukan karyawan ketika baik. Hasilperhitungan pada tabel di responden mendatangi PT. PUSRI atas memperlihatkan bahwa sebagian Palembang . Sebanyak IO responden konsumen merasapenyambutan yang menyatakan sangat baik, I9 dilakukan karyawan ketika konsumen respondenmenyatakan baik, IO mendatangi PT. PUSRI Palembang responden menyatakan cukup baik, PPD Lampung adalah sudah baik.

\section{Tabel 3.}

Pertanyaan No. 2. Apakah cara karyawan menjelaskan tentang produk PT. PUSRI Palembang PPD Lampung yangditawarkan kepada Anda sudah sangat baik

\begin{tabular}{|l|r|r|r|r|}
\hline & Frequency & Percent & \multicolumn{1}{|c|}{$\begin{array}{c}\text { Valid } \\
\text { Percent }\end{array}$} & $\begin{array}{c}\text { Cumulative } \\
\text { Percent }\end{array}$ \\
\hline Valid Sangat Tidak & 5 & $9 . \mathrm{I}$ & $9 . \mathrm{I}$ & $9 . \mathrm{I}$ \\
Baik & & & & \\
Tidak Baik & II & 20.0 & 20.0 & $29 . \mathrm{I}$ \\
Cukup Baik & II & 20.0 & 20.0 & $49 . \mathrm{I}$ \\
Baik & I7 & 30.9 & 30.9 & 80.0 \\
Sangat Baik & II & 20.0 & 20.0 & I00.0 \\
Total & 55 & I00.0 & I00.0 & \\
\hline
\end{tabular}

Pada tabel 3 terlihat pandangan sangat tidak baik. Hasil perhitungan responden terhadap cara karyawan pada tabel di atasmemperlihatkan bahwa menjelaskantentang produk PT. PUSRI sebagian konsumen merasa Palembang PPD Lampung yang carakaryawan menjelaskantentang ditawarkan kepada responden adalah produk PT. PUSRI Palembang PPD sebanyak IIresponden menyatakan Lampung yang ditawarkan sangat baik, I7 responden menyatakan kepadakonsumen adalah sudah baik. baik, II responden menyatakan cukup baik, I responden menyatakan tidak baik, dan 5 respondenmenyatakan 
Tabel 4.

Pertanyaan No.3. Menurut Anda apakah karyawanPT. PUSRI Palembang PPD Lampung memiliki penguasaan yang baik tentangproduk atau pupuk yang ditawarkan

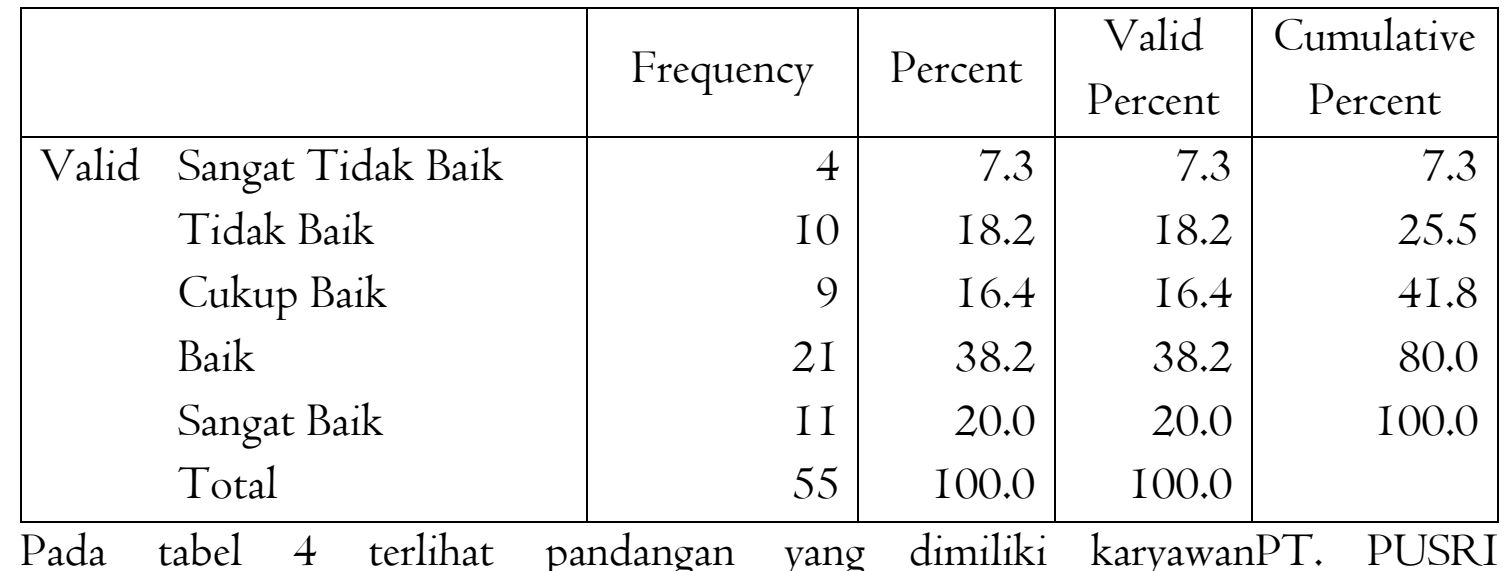
responden terhadap penguasaan yang Palembang PPD Lampung tentang dimiliki karyawanPT.Hasil perhitungan produk atau pupuk yang ditawarkan pada tabel di atasmemperiihatkan bahwa kepada konsumen adalah sudahbaik. sebagian konsumen merasa penguasaan

Tabel 5.

Pertanyaan No.4. Menurut Anda apakah carakaryawanPT. PUSRI Palembang PPD Lampung menyajikan produk atau pupuk yang cepat sudah sangat baik dilakukan

\begin{tabular}{|l|r|r|r|r|}
\hline & Frequency & Percent & \multicolumn{1}{|c|}{$\begin{array}{c}\text { Valid } \\
\text { Percent }\end{array}$} & $\begin{array}{c}\text { Cumulative } \\
\text { Percent }\end{array}$ \\
\hline Valid Sangat Tidak & I & I.8 & I.8 & I.8 \\
Baik & II & 20.0 & 20.0 & 21.8 \\
Tidak Baik & I4 & 25.5 & 25.5 & 47.3 \\
Cukup Baik & I6 & $29 . \mathrm{I}$ & $29 . \mathrm{I}$ & 76.4 \\
Baik & I3 & 23.6 & 23.6 & I00.0 \\
Sangat Baik & 55 & I00.0 & I00.0 & \\
Total & I0.0 \\
\hline
\end{tabular}

Pada tabel 5 terlihat pandangan responden terhadap cara karyawanPT. PUSRI Palembang PPD Lampung Menyajikanpelayanan atau pupukdengan cepat. Hasil perhitungan pada tabel di atasmemperlihatkan bahwa sebagian konsumen merasa carakaryawanPT. PUSRI Palembang PPD Lampung menyajikan produk atau pupuk yang cepat kepada konsumen adalah sudahbaik. 
Tabel 6.

Pertanyaan No.5 Menurut Anda apakah carakaryawanPT. PUSRI Palembang PPD Lampung dalam memastikan Anda menerimauang kembalian yang benar sudah sangat baik dilakukan

\begin{tabular}{|c|c|c|c|c|c|}
\hline & \multirow{3}{*}{$\begin{array}{r}\text { Frequency } \\
3\end{array}$} & \multirow{2}{*}{$\begin{array}{r}\text { Percent } \\
5.5\end{array}$} & $\begin{array}{c}\text { Valid } \\
\text { Percent }\end{array}$ & $\begin{array}{c}\text { Cumulative } \\
\text { Percent }\end{array}$ \\
\hline Valid & Sangat $\quad$ Tidak & & & 5.5 & 5.5 \\
\hline & Baik & & & & \\
\hline & Tidak Baik & 7 & I2.7 & I2.7 & I8.2 \\
\hline & Cukup Baik & 10 & I8.2 & I8.2 & 36.4 \\
\hline & Baik & 23 & $4 \mathrm{I} .8$ & $4 \mathrm{I} .8$ & 78.2 \\
\hline & Sangat Baik & $\mathrm{I} 2$ & 21.8 & 21.8 & I00.0 \\
\hline & Total & 55 & I00.0 & I00.0 & \\
\hline
\end{tabular}
responden terhadap carakaryawanPT. konsumen merasa carakaryawan PT. PUSRI Palembang PPD Lampung PUSRI Palembang PPD Lampung dalam memastikan responden menerima dalam memastikan responden menerima uang kembalian yang benar. Hasil uang kembalian yang benar adalah perhitungan pada tabel di sudah baik.

\section{Tabel 7.}

Pertanyaan No. 6 Pada KuesionerMenurut Anda apakah keluhan-keluhan yang Anda sampaikan untuk dapat diperbaiki diterima dengan sangat baik oleh karyawan PT. PUSRI Palembang PPD Lampung

\begin{tabular}{|l|r|r|r|r|}
\hline & Frequency & Percent & \multicolumn{1}{|c|}{$\begin{array}{c}\text { Valid } \\
\text { Percent }\end{array}$} & $\begin{array}{c}\text { Cumulative } \\
\text { Percent }\end{array}$ \\
\hline Valid Sangat Tidak & 4 & 7.3 & 7.3 & 7.3 \\
Baik & & & & \\
Tidak Baik & 9 & I6.4 & I6.4 & 23.6 \\
Cukup Baik & 7 & I2.7 & I2.7 & 36.4 \\
Baik & 27 & $49 . \mathrm{I}$ & $49 . \mathrm{I}$ & 85.5 \\
Sangat Baik & 8 & I4.5 & I4.5 & I00.0 \\
Total & 55 & I00.0 & I00.0 & \\
\hline
\end{tabular}


Pada table 7terlihat pandangan Lampung adalah sebanyak 8 responden responden terhadap keluhan-keluhan menyatakan sangat baik,27 responden yangdisampaikan responden untuk menyatakanbaik, 7 responden dapat diperbaiki dan diterima oleh menyatakan cukup baik, 9 responden karyawanPT. PUSRI Palembang PPD menyatakan tidak baik,dan 4 responden menyatakan sangat tidak baik

Tabel 8.

Pertanyaan No.7Pada Kuisioner Menurut Anda apakahkaryawanPT. PUSRI Palembang PPD Lampung memiliki ketanggapan yang sangat baik mengenai kebutuhan Anda

\begin{tabular}{|l|c|c|c|c|}
\hline & Frequency & Percent & $\begin{array}{c}\text { Valid } \\
\text { Percent }\end{array}$ & $\begin{array}{c}\text { Cumulative } \\
\text { Percent }\end{array}$ \\
\hline Valid Sangat Tidak & 3 & 5.5 & 5.5 & 5.5 \\
Baik & 9 & I6.4 & I6.4 & 21.8 \\
Tidak Baik & 9 & I6.4 & I6.4 & 38.2 \\
Cukup Baik & I7 & 30.9 & 30.9 & 69.1 \\
Baik & I7 & 30.9 & 30.9 & I00.0 \\
Sangat Baik & 55 & I00.0 & I00.0 & \\
Total & \multicolumn{3}{|c|}{ respondenmenyatakan sangat tidak baik. }
\end{tabular}
responden terhadap ketanggapan yang Hasil perhitungan pada tabel di dimilikioleh karyawan PT. PUSRI atasmemperlihatkan bahwa sebagian Palembang PPD Lampung mengenai konsumen merasa ketanggapan yang kebutuhan responden adalah sebanyak dimilikioleh karyawanPT. PUSRI I7responden menyatakan sangat baik, Palembang PPD Lampung mengenai I7 responden menyatakan baik, 9 kebutuhan konsumen adalah sudah respondenmenyatakan cukup baik, 9 sangat baik.

responde menyatakan tidak baik, dan 3 
Tabel9.

Pertanyaan No. 8 Pada KuesionerMenurut Anda apakah pelayanan yang diberikan oleh staf dan atau karyawan PT. PUSRI Palembang PPD Lampung yang selalu siap sedia saat diperlukan sudah sangat baik dilakukan

\begin{tabular}{|c|c|c|c|c|c|}
\hline & & Frequency & Percent & $\begin{array}{c}\text { Valid } \\
\text { Percent }\end{array}$ & $\begin{array}{l}\text { Cumulative } \\
\text { Percent }\end{array}$ \\
\hline Valid & Sangat Tidak & 5 & 9.I & 9.I & 9.I \\
\hline & Baik & & & & \\
\hline & Tidak Baik & 6 & 10.9 & 10.9 & 20.0 \\
\hline & Cukup Baik & IO & I8.2 & I8.2 & 38.2 \\
\hline & Baik & 20 & 36.4 & 36.4 & 74.5 \\
\hline & Sangat Baik & I4 & 25.5 & 25.5 & I00.0 \\
\hline & Total & 55 & I00.0 & I00.0 & \\
\hline
\end{tabular}

Pada tabel 9 terlihat pandangan menyatakan tidak baik, dan 5responden responden terhadap pelayanan yang diberikanoleh staf dan atau karyawan PT. PUSRI Palembang PPD Lampung yang selalu siap sedia saat diperlukan adalahsebanyak I4 responden menyatakan sangat baik, 20 responden menyatakan baik, I0 responden menyatakan cukup baik, 6 responden menyatakan sangat tidak baik.

Hasil perhitungan pada tabel di atasmemperlihatkan bahwa sebagian konsumen merasa pelayanan yang diberikanoleh staf dan atau karyawanPT. PUSRI Palembang PPD Lampung yang selalu siap sedia saat diperlukan adalahsudah baik dilakukan.

\section{Tabello.}

Pertanyaan No.9 Pada KuesionerMenurut Anda apakah pemberian informasi yang jelas dan cepat sudah dilakukandengan sangat baik oleh karyawanPT. PUSRI Palembang PPD Lampung

\begin{tabular}{|l|r|r|r|r|}
\hline & Frequency & Percent & \multicolumn{1}{|c|}{$\begin{array}{c}\text { Palid } \\
\text { Percent }\end{array}$} & $\begin{array}{c}\text { Cumulative } \\
\text { Percent }\end{array}$ \\
\hline Valid Sangat Tidak & 4 & 7.3 & 7.3 & 7.3 \\
Baik & & & & \\
Tidak Baik & 5 & 9.1 & 9.1 & I6.4 \\
Cukup Baik & I5 & 27.3 & 27.3 & 43.6 \\
Baik & 24 & 43.6 & 43.6 & 87.3 \\
Sangat Baik & 7 & I2.7 & I2.7 & I00.0 \\
Total & 55 & I00.0 & I00.0 & \\
\hline
\end{tabular}


Pada tabel I0 terlihat pandangan responden terhadap pemberian informasi yangjelas dan cepat yang dilakukan oleh karyawanPT. PUSRI Palembang PPD Lampung adalah sebanyak $\quad 7 \quad$ respondenmenyatakan sangat baik,24 responden menyatakan baik, I5 respondenmenyatakan cukup baik, 5 responden menyatakan tidak baik, dan 4 responden menyatakan sangat tidak baik. Hasil perhitungan pada tabel di atasmemperlihatkan bahwa sebagian konsumen merasa pemberian informasi yangjelas dan cepat yang dilakukan oleh karyawan PT. PUSRI Palembang PPD Lampung adalah sudah baik dilakukan.Berikut ini merupakan perhitungan analisis kuantitatif mengenai hubungankualitas pelayanan dengan kepuasan konsumen (product momen)t:

$$
\begin{aligned}
& r_{x y} \\
& =\frac{N \sum X Y-\left(\sum X\right)\left(\sum Y\right)}{\sqrt{\left\{N \sum X^{2}-\left(\sum X\right)^{2}\right\}\left\{N \sum Y^{2}-\left(\sum Y\right)^{2}\right\}}}
\end{aligned}
$$
maka korelasi antara variabel kualitas pelayanan dengan kepuasan konsumen menunjukkan angka sebesar 0,804. Angka tersebutmenunjukkan adanya korelasi (hubungan) yang sangat kuat dan searah antarakualitas pelayanandengan kepuasan konsumen dalam meningkatkan volumepenjualan pada PT. PUSRI Palembang PPD Lampung karena terletak pada intervalkoefisien 0,75-I.Dan dikatakan searah karena hasil perhitungan diatasmenunjukkan angka yang positif, artinya jika variabel kualitas pelayanan besarmaka variabel kepuasan konsumen menjadi besar pula. Hal ini berarti jika PT. PUSRI Palembang PPD Lampung meningkatkan kualitas pelayanannya maka kepuasankonsumen juga akan meningkat. Pengujian hipotesis terhadaprdengan menggunakan rumus statistik $\mathrm{t}$ adalahsebagai berikut:

$\mathrm{t}=\frac{\mathrm{r} \sqrt{\mathrm{N}-2}}{\sqrt{\mathrm{I}-\mathrm{r}^{2}}}$ dengan $\mathrm{df}=55-2=53$

Berdasarkan hasil perhitungan tersebut diketahui bahwa nilai $\mathrm{t}$ hitungyang diperoleh sebesar 9,843, Dimana nilai t tabel diperoleh dengan ketentuan $\mathrm{df}=$ jumlah sampel-2 atau $55-2=53$, dengan tingkat signifikansi sebesar 5\% atau0,05. Nilai tabel yang diperoleh adalah sebesar I,674I. Hal ini menunjukkanbahwa $\mathrm{t}$ hitung $>$ tabel atau 9,843 > I,674I sehingga Ho ditolak dan menerirna $\mathrm{Ha}$ yang berarti ada hubungan antara kualitas pelayanan dengan kepuasan konsumendalam meningkatkan volume penjualan pada PT. PUSRI Palembang PPD Lampung. 
IKONOMIKA

Volume I, Nomor2, Oktober 2016

Hasil perhitungan dengan berhubungandengan kepuasan menggunakan rumus konsumen dalam meningkatkan volume korelasiproductmomentterhadaplima sub variabel yang menjadi penentu PPD Lampung dapat dilihat pada tabel kualitas pelayanan yang I3 berikut ini:

\section{TabelII.}

Data X (Kualitas pelayanan) dan Y (Kepuasan konsumen)Untuk Lima Sub

Variabel

\begin{tabular}{|c|l|c|c|c|c|c|c|}
\hline $\begin{array}{c}\mathrm{N} \\
\mathrm{o}\end{array}$ & \multicolumn{1}{|c|}{ Sub Variabel } & $\mathrm{X}$ & $\mathrm{Y}$ & $\mathrm{XY}$ & $\mathrm{X}^{2}$ & $\mathrm{Y}^{2}$ & $r$ \\
\hline $\mathrm{I}$ & Kehandalan (Reability) & 949 & 830 & $\begin{array}{c}\mathrm{I} 487 \\
3\end{array}$ & $\begin{array}{c}\mathrm{I} 786 \\
3\end{array}$ & $\mathrm{I} 2998$ & 0,658 \\
\hline 2 & $\begin{array}{l}\text { Ketanggapan } \\
\text { Responsiveness) }\end{array}$ & 779 & $67 \mathrm{I}$ & 9759 & $\begin{array}{c}\mathrm{II} 93 \\
9\end{array}$ & 8469 & 0,504 \\
\hline 3 & Jaminan (Assurance) & $8 \mathrm{I} 9$ & 688 & $\begin{array}{c}\mathrm{I} 052 \\
\mathrm{I}\end{array}$ & $\begin{array}{c}\mathrm{I} 280 \\
\mathrm{I}\end{array}$ & 8924 & 0,629 \\
\hline 4 & Empati (Emphaty) & 447 & 335 & $\begin{array}{l}2779 \\
377 \mathrm{I}\end{array}$ & $2 \mathrm{I} 43$ & 0,474 \\
\hline 5 & Wujud nyata (Tangible) & $\mathrm{I06I}$ & 840 & $\begin{array}{c}\mathrm{I} 652 \\
2\end{array}$ & $\begin{array}{c}2 \mathrm{III} \\
3\end{array}$ & $\begin{array}{c}\mathrm{I} 3335 \\
8\end{array}$ & 0,545 \\
\hline
\end{tabular}

Dari hasil perhitungan diatas

(hubungan) yang kuat dan searah antara maka korelasi antara variabel kualitas kualitas pelayanan dengankepuasan pelayanandengan kepuasankonsumen konsumen pada masing-masing sub untuk sub variabel kehandalan variabel tersebut dalammeningkatkan (reability)menunjukkan angka sebesar volume penjualan pada PT. PUSRI 0,658, sub variabel ketanggapan Palembang PPD Lampung. Hal ini (responsiveness)menunjukkan angka berarti jika PT. PUSRI Palembang sebesar 0,504, sub variabel jaminan PPD Lampung meningkatkan (assurance)menunjukkan angka sebesar kualitaspelayanannya pada setiap sub 0,629, dan sub variabel wujud nyata variabel diatas maka kepuasan (tangible)menunjukkan angka sebesar konsumen padasetiap sub variabel diatas 0,545 .

Angka-angka

tersebut

menunjukkan adanya korelasi juga akan meningkat. 


\section{SIMPULAN}

Berdasarkan hasil perhitungan dan pembahasan maka dapat diambil kesimpulanbahwa

I. Hasil perhitungan dengan rumus korelasiproduct moment yaitu sebesar 0,804dengan $n=55$. Angka tersebut terletak pada interval koefisien 0,75 - I yangberarti hubungan antara kualitas pelayanan dengan kepuasan pelanggandalam meningkatkan volume penjualan pada PT. PUSRI Palembang PPD Lampung adalah sangat kuat.

2. Berdasarkan kriteria hipotesis, jika t hitung $>$ trabel maka Ho ditolak danmenerima Ha yang berarti ada hubungan antara kualitas pelayanan dengankepuasan pelanggan, dan jika $\mathrm{t}$ hitung $<\mathrm{t}$ tabel maka Ho diterima dan menolak Ha yang berarti tidak ada hubungan antara kualitas pelayanan dengan kepuasanpelanggan.
Sedangkan dari hasil perhitungan diketahui bahwa nilai $\mathrm{t}$ hitung yang diperoleh sebesar 9,843 dan nilai $t$ hitung yang diperoleh adalah sebesarI,674Idengan ketentuan $\mathrm{df}$ $=$ jumlah sampel -2 atau $55-2=$ 53, dan tingkatsignifikansi sebesar $5 \%$ atau0,05. Hal ini menunjukkan bahwa nilai $\mathrm{t}$ hitung $>$ tabel yaitu 9,843 $>$ I,674Iyang berarti terdapat hubungan antara kualitaspelayanan dengan kepuasan pelanggan dalam meningkatkan volumepenjualan pada PT. PUSRI Palembang PPD Lampung. Berdasarkan analisis kualitatif dapat diambil kesimpulan bahwa kinerjapelayanan yang dilakukan oleh PT. PUSRI Palembang PPD Lampung belum menghasilkan kepuasan yang maksimal yaitu pelayanan yang diberikanbelum sesuai dengan harapan pelanggan (konsumen).

\section{DAFTAR PUSTAKA}

Ari Prasetio, (2012), Pengaruh Kualitas Pelayanan Dan Harga Terhadap Kepuasan Pelanggan, Management Analysis Journal I (2) (2012)

Auli Lucky Yuriansyah, (20I3), Persepsi Tentang Kualitas Pelayanan, Nilai

Produk Dan Fasilitas Terhadap Kepuasan Pelanggan, ISSN 2252-6552,

Management AnalysisJournal, 2 (I) (2013)

Basrah Saidani, (2012), Pengaruh Kualitas Produk Dan Kualitas Layanan Terhadap

Kepuasan Konsumen Dan Minat Beli Pada Ranch Market, Jurnal Riset

Manajemen Sains Indonesia (JRMSI) | Vol. 3, No. I, 2012

Catur Martian Fajar \& A. Rohendi, (2016), Keadilan Organisasi, Kepuasan Kerja 
Dan Pemberdayaan Pegawai Yang Berdampak Pada Komitmen Organisasi, Ikonomika, Jurnal Ekonomi Dan Bisnis Islam (Journal Of Islamic Economics And Business) Volume I, Nomor I, Mei 2016

Dibyantoro, Alhushori, Rini Gustriani, (20I2), Pengaruh Kualitas Pelayanan

Terhadap Kepuasan Nasabah Pada Tabungan BTN Batara Studi Kasus: PT

Bank Tabungan Negara (Persero) Cabang Palembang, Jurnal Ekonomi Dan

Informasi Akuntansi (JENIUS), Vol. 2 No. 3 Sept 2012

Ferninda Manoppo, Kualitas Pelayanan, Dan Servicescape Pengaruhnya Terhadap

Kepuasan Konsumen Pada Hotel Gran Puri Manado, Jurnal EMBA, ISSN

2303-I 174, Vol.I No.4 Desember 20I3, Hal. I34I-I348

Kotler, Philip. 2012. Manajemen Pemasaran di Indonesia, Analisis, Perencanaan,

Implementasi, dan Kontrol. Buku I. Penelitian Salemba Empat. Jakarta.

Kotler, Philip. 20I2.Manajemen Pemasaran Perspektif Asia. Buku I. Indeks.Jakarta

Rustika Atmawati dan M. Wahyuddin, (2004), Analisis Pengaruh Kualitas

Pelayanan Terhadap Kepuasan Konsumen Pada Matahari Departement Store Di Solo Grand Mall, Jurnal Ekonomi Manajemen Sumber DayaVol. 5, No. I, Juni 2004

Sarwono, Jonathan. 2013. Analisis Data Penelitian Menggunakan SPSS. Penerbit ANDI. Yogyakarta

Selvy Normasari, Srikandi Kumadji, Andriani Kusumawati, (2013), Pengaruh

Kualitas Pelayanan Terhadap Kepuasan Pelanggan, Citra Perusahaan Dan

Loyalitas Pelanggan, Survei Padatamu Pelanggan Yang Menginap Di Hotel

Pelangi Malang, Jurnal Administrasi Bisnis (JAB) | Vol. 6 No. 2 Desember 2013

Tulus Suryanto, (2016), PengaruhAccounting Disclosure, Accounting HarmonizationDan Komite Audit Terhadap Kualitas Laba (Studi Pada Perusahaan Manufaktur Yang Terdaftar Di BEI), Jurnal Akuntansi/Volum XX,No. 02, Mei 20I6: I90-20I

Umar, Husein. 20I I. Metode Riset Bisnis. Penerbit PT Gramedia Pustaka Utama. Jakarta. 